\title{
Description of Eimeria arabukosokokensis sp. n. (Apicomplexa: Eimeriidae) from Telescopus semiannulatus (Serpentes: Colubridae) with notes on eimerian coccidia from snakes of Eastern Kenya
}

\author{
Jan R. Šlapeta ${ }^{1}$, David Modrý ${ }^{1,2}$, James Ashe $^{3}$ and Břetislav Koudela ${ }^{1,2}$ \\ ${ }^{1}$ Department of Parasitology, University of Veterinary and Pharmaceutical Sciences Brno, Palackého 1-3, 61242 Brno, Czech \\ Republic; \\ ${ }^{2}$ Institute of Parasitology, Academy of Sciences of the Czech Republic, Branišovská 31, 37005 České Budějovice, Czech \\ Republic; \\ ${ }^{3}$ Bio-Ken Snake Farm, P.O. BOX 3, Watamu, Kenya
}

Key words: Coccidia, Apicomplexa, Caryospora, Eimeria, morphology, taxonomy, Reptilia, Serpentes

\begin{abstract}
Parasitological examination of faeces of 26 snakes kept in Bio-Ken Snake Farm, Watamu, Kenya revealed new species of Eimeria Schneider, 1875 in Telescopus semiannulatus Smith, 1849. Oocysts of Eimeria arabukosokokensis sp. n. are cylindrical $26.8(25-29) \times 15.1(14-16) \mu \mathrm{m}$ with smooth, bilayered oocyst wall and a single polar granule. The broadly ellipsoidal sporocysts average $9.3(8.5-10) \times 7.1(6.5-7.5) \mu \mathrm{m}$ and possess single-layered wall composed of two plates joined by longitudinal suture. Caryospora cf. regentensis Daszak et Ball, 2001 is reported from Dendroaspis angusticeps (Smith, 1849) and two additional forms of Caryospora Léger, 1904 are reported and morphologically characterised from a single specimen of Psammophis orientalis Broadley, 1977. Systematic status of Caryospora spp. in sub-Saharan Psammophis Boie, 1827 is discusses and all species reported by various authors to date are suggested to be treated as species inquirendae until more detailed data on these parasites and their hosts are available.
\end{abstract}

Coccidia of the family Eimeriidae parasitizing reptilian hosts comprise predominantly members of the genera Caryospora Léger, 1904, Eimeria Schneider, 1875 and Isospora Schneider, 1881 (e.g., Upton et al. 1986, McAllister et al. 1995, Modrý 1999). In contrast to the large diversity of African snakes, only a limited knowledge exists about the coccidian species parasitizing these hosts. In an attempt to shed more light on the parasitofauna of East African snakes, we have performed a coprological examination of several snake species kept in Bio-Ken Snake Farm in Eastern Kenya. These examinations revealed a diverse spectrum of coccidia which are reported below, together with a description of one new species.

\section{MATERIALS AND METHODS}

Faecal samples were collected from 26 snakes, representing 18 species in five families: (numbers of examined specimens are noted in parentheses) Elapidae: Naja nigricollis Reinhardt, 1843 (2), Naja pallida Boulenger, 1896 (1), Dendroaspis angusticeps (Smith, 1849) (1); Viperidae: Bitis arietans (Merrem, 1820) (2), Bitis gabonica (Duméril, Bibron et Duméril, 1854) (1), Causus resimus (Peters, 1862) (2), Echis pyramidum (Geoffroy Saint-Hilaire, 1827) (1); Atractaspid-idae: Atractaspis microlepidota Günther, 1866 (2); Colubri-dae: Lamprophis fuliginosus (Boie, 1827) (2), Philothamnus punctatus Peters, 1867 (1), Mehelya capensis (Smith, 1847) (1), Telescopus semiannulatus Smith, 1849 (3),
Dasypeltis medici (Bianconi, 1859) (1), Rhamphiophis rubropunctatus (Fischer, 1884) (2), Scaphiophis albopunctatus Peters, 1870 (1), Psammophis orientalis Broadley, 1977 (1), Dispholidus typus (Smith, 1829) (1); Boidae: Eryx colubrinus (Linnaeus, 1758) (1). Examined animals were kept in Bio-Ken Snake Farm, Watamu, Kenya. Animals originated mostly from the localities in coastal Kenya; in described cases the locality is given in a species account. All samples were stored in individual tubes with $2.5 \%$ potassium dichromate, transported to laboratory and examined for the presence of parasites using flotation technique. Morphological examinations and photo-graphy was performed using an Olympus Provis microscope equipped for Nomarski interference contrast (NIC) micro-scopy. All measurements are given in $\mu \mathrm{m}$ as means followed by ranges in parentheses. The snake taxonomy used throughout this paper reflects the most recent opinion by Spawls et al. (2002).

\section{RESULTS}

Nine of 26 samples examined (35\%) contained coccidian oocysts. Sporocysts of Sarcocystis spp., found in four snakes (Lamprophis fuliginosus, Mehelya capensis, Rhamphiophis rubropunctatus, Psammophis orientalis), were the most prevalent. Oocysts of Caryospora were observed in three snakes (Telescopus semiannulatus, Psammophis orientalis, Dendroaspis angusticeps), and oocysts of Eimeria s.l. in three Telescopus semiannulatus and one Lamprophis 

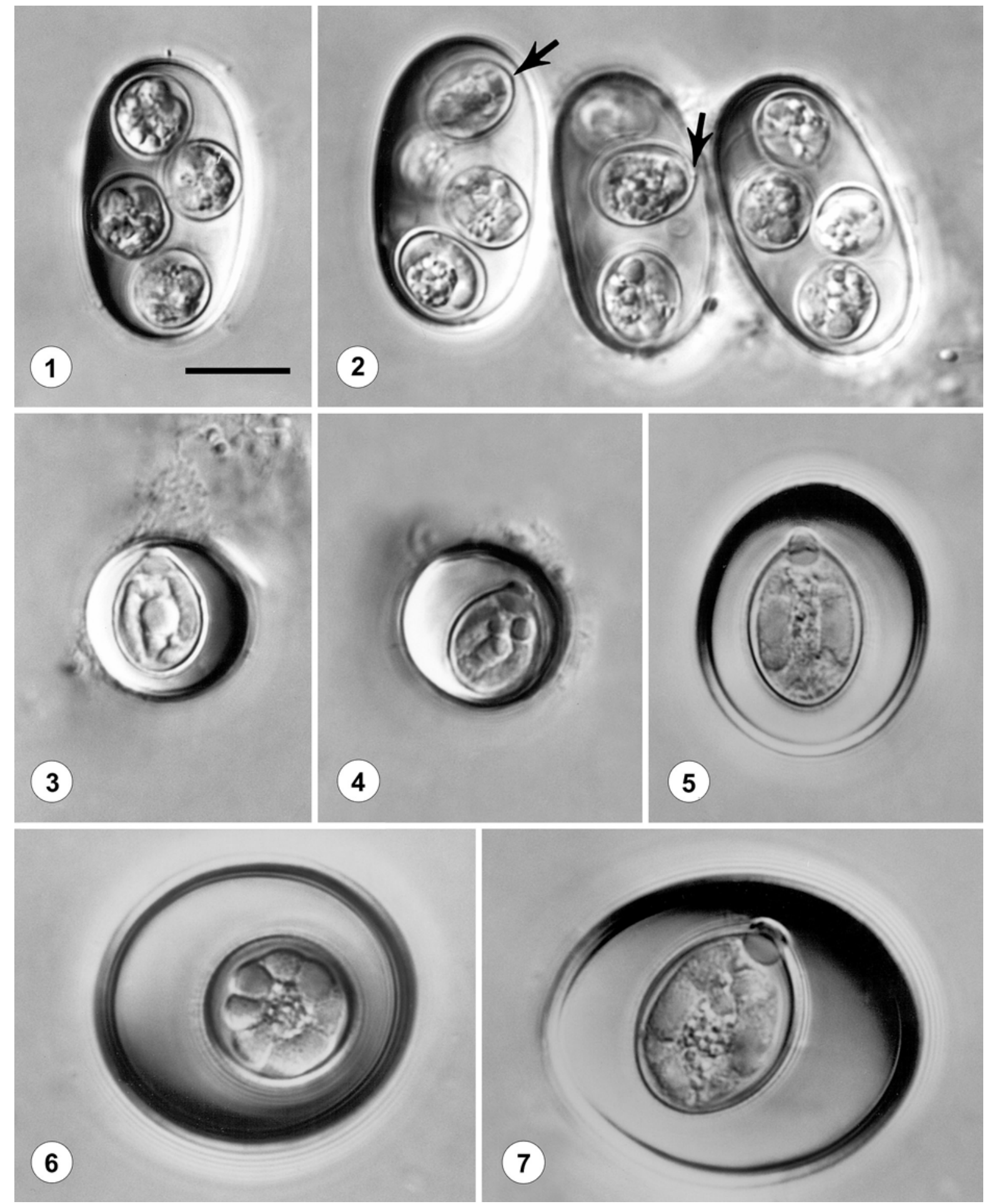

Figs. 1-7. Nomarski interference contrast photographs of sporulated oocysts of found coccidia, all in the same scale. Figs. 1-2. Eimeria arabukosokokensis sp. n. from Telescopus semiannulatus. Note visible sutures of sporocyst wall plates (arrows). Figs. 3-4. Caryospora cf. regentensis from Dendroaspis angusticeps. Fig. 5. Caryospora sp. I from Psammophis orientalis. Fig. 6. Caryospora sp. II from P. orientalis, transversal view. Fig. 7. Caryospora sp. II from P. orientalis, longitudinal view. Scale bar $=10 \mu \mathrm{m}$. 


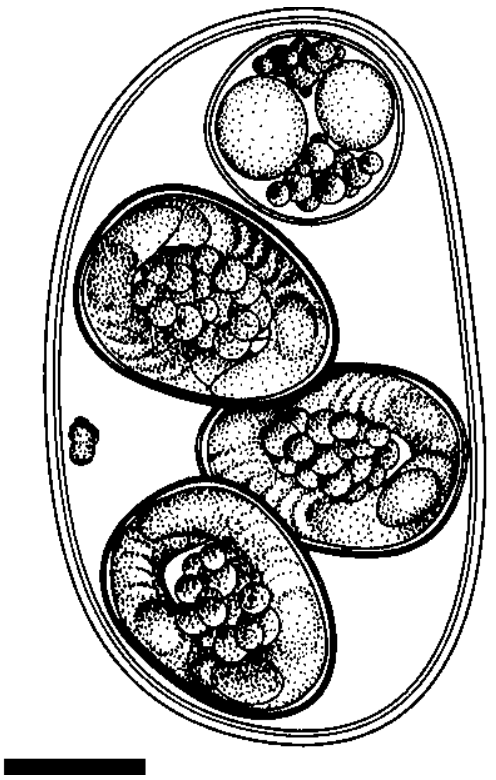

Fig. 8. Composite line drawing of sporulated oocyst of Eimeria arabukosokokensis sp. n. Scale bar $=5 \mu \mathrm{m}$.

fuliginosus. Only three Caryospora spp. and a single Eimeria sp. had sufficient number of sporulated oocysts to be morphologically further characterised.

\section{APICOMPLEXA: E i m e r i i d a e}

\section{Eimeria arabukosokokensis sp. n.}

Figs. 1-2, 8

Description: Oocysts cylindrical, long sides almost parallel to each other; $26.8(25-29) \times 15.1(14-16)$, shape index (length:width ratio, SI) $=1.8(1.6-1.9)(\mathrm{n}=$ 30 ). Oocyst wall smooth, bilayered, approximately 2 thick, with inner layer being thinner. Single polar granule present. Sporocysts broadly ellipsoidal, broader toward one end, $9.3(8.5-10) \times 7.1(6.5-7.5)$, SI $=1.3$ $(1.2-1.5)(\mathrm{n}=30)$. Sporocyst wall thin, smooth, singlelayered, composed of two plates joined by longitudinal suture. Sporozoites with one refractile body and barely visible nucleus located centrally. Surface of bananashaped sporozoites appeared striated or finely granular. Sporocyst residuum consists of numerous globules 11.5 in diameter, forming a spherical cluster 3-4 in diameter or being scattered among sporozoites.

$\mathrm{T}$ y $\mathrm{p}$ e $\mathrm{h}$ o st : Telescopus semiannulatus Smith, 1849 (Serpentes, Colubridae, Boiginae).

T y p e 1 o c a 1 i t y : Watamu near Malindi, coastal area of Kenya (ca. $03^{\circ} 21^{\prime} \mathrm{S}, 40^{\circ} 01^{\prime} \mathrm{E}$ ), Africa.

$\mathrm{S}$ i t e of i n f e c t i o $\mathrm{n}$ : Unknown, oocysts recovered from faeces; probably the gall bladder (see Remarks).

P r e v a l e n c e: All 3 examined snakes expelled oocysts in faeces.
T y p e $\mathrm{m}$ a $\mathrm{t}$ e $\mathrm{r}$ i a 1 : Photosyntypes deposited under the original collection No. KA31/1999 at Department of Parasitology, University of Veterinary and Pharmaceutical Sciences Brno, Czech Republic.

E t y m o lo g y : The name is derived from the local name of nearby situated Arabuko-Sokoke Forest in coastal East Africa, in honour of this unique and endangered place.

Remarks: Based on the oocyst shape (cylindrical) and the absence of Stieda and substieda body, the studied isolate probably belongs to Choleoeimeria Paperna et Landsberg, 1989 as defined by Paperna and Landsberg (1989a, b) rather than to Eimeria. However, such classification has been questioned and not accepted or simply ignored by several authors (e.g., Asmundsson et al. 2001, Daszak and Ball 2001a). Therefore, we follow a recently used wider concept of Eimeria; for details see Discussion. The endogenous development of all histologically studied species of Eimeria with elongated cylindrical oocysts is confined to the gall bladder epithelium (e.g., Paperna and Landsberg 1989a, b, Paperna and Lainson 2000, Modrý et al. 2001). Thus, it is probable that $E$. arabukosokokensis also affects this organ.

Caryospora cf. regentensis Daszak et Ball, 2001

Figs. 3-4, 9

Description: Oocysts spherical, $15.3(14.5-16) \times$ $15.0(14-16), \mathrm{SI}=1.0(1.0-1.1)(\mathrm{n}=30)$. Oocyst wall smooth and bilayered, $\sim 1$ thick, inner layer thinner, outer layer yellowish. Micropyle and oocyst residuum absent. Spherical polar granule present in $60 \%$ of oocysts examined. Sporocysts ellipsoidal, 10.9 (10-12) $\times 8.2(6.5-9)$, SI $=1.3(1.2-1.5)(\mathrm{n}=30)$. Sporozoites with one barely visible refractile body and almost invisible, centrally located nucleus. Surface of bananashaped sporozoites smooth. Sporocyst residuum usually compact, spherical, 3-4 × 1.5-3.5 in diameter, often accompanied by up to 5 globules scattered among sporozoites. Eight sporozoites, 1.5-2 in diameter, fill tightly sporocyst. Stieda body ellipsoidal, 1.5-2 $\times 0.5$, substieda body ellipsoidal, $2.5-3 \times 1.5$.

H o s t : Dendroaspis angusticeps (Smith, 1849), the green mamba (Serpentes, Elapidae).

L o c a 1 i t y : Watamu near Malindi, coastal area of Kenya (ca. $03^{\circ} 21^{\prime} \mathrm{S}, 40^{\circ} 01^{\prime} \mathrm{E}$ ).

$\mathrm{S}$ it e of in fecti o n: Unknown, oocysts recovered from faeces.

P r e v a 1 e n c e : Single examined sample originated from a colony of dozens of green mambas in Bio-Ken, where the snakes are used for venom milking.

$\mathrm{S}$ i t e of infecti o $\mathrm{n}$ : Unknown, oocysts recovered from faeces.

Vo u c h e r m a t e ri a 1 : Oocyst microphotographs deposited under the original collection No. KA26/1999 at Department of Parasitology, University of Veterinary and Pharmaceutical Sciences Brno, Czech Republic. 
Remarks: The morphology of the found isolate matches the original description of Caryospora regentensis Daszak et Ball, 2001. Sporocysts of $C$. regentensis were originally described to be 13.0 (10.2$14.1) \times 10.3(9.3-11.1)$ and, thus, exceed slightly the data presented herein. Slight differences also could be observed in the shape of the Stieda body (originally noted to be of the same length and width); in the organisation of the sporocyst residuum; and 60\%presence of the polar granule (originally reported to be present in $100 \%$ of oocysts). Caryospora regentensis was originally described in error from Dendroaspis viridis, but the host determination was soon after corrected in the published erratum to Dendroaspis angusticeps (Daszak and Ball 2001b). The conspecificity of the original host with animals reported herein, together with the fact that both reports deal with animals from Kenya, supports the conspecific status of our isolate with $C$. regentensis. Described fine morphological differences can be caused by some level of subjectivity in descriptions, by biological variation or by changes subsequent to the sporulation.

\section{Caryospora sp. I}

Figs. 5, 10

Description: Oocysts oval, $23.8(22-25.5) \times 20.5$ $(19-22)$, SI $=1.2(1.1-1.3)(\mathrm{n}=30)$. Oocyst wall smooth and bilayered, approximately 1.5 thick, with inner layer thinner than outer, outer layer yellowish. Micropyle, oocyst residuum and polar granule absent. Sporocysts oval, $15.5(15-16) \times 11.0(10-12)$, SI $=1.4$ $(1.2-1.6) \quad(\mathrm{n}=30)$. Each sporozoite with distinct broadly oval nucleus, refractile bodies barely visible. Surface of banana-shaped sporozoites transversally striated. Sporocyst residuum usually consists of a few small globules $<1$ in diameter arranged symmetrically and filling tightly sporocyst. Stieda body ellipsoidal, 2.5-3 $\times 1$, substieda body ellipsoidal, 3-3.5 × 1.5.

H o s t : Psammophis orientalis Broadley, 1977 (Serpentes, Colubridae).

L o c a 1 i t y : Watamu near Malindi, coastal area of Kenya, Africa.

P r e v a 1 e $\mathrm{n}$ c e : Isolated from a single specimen examined.

$\mathrm{S}$ i t e of in f e c t i o n: Unknown, oocysts recovered from faeces.

Vo u c h e r m a t e r i a 1 : Oocyst microphotographs deposited under the original collection No. KA24/1999 at Department of Parasitology, University of Veterinary and Pharmaceutical Sciences Brno, Czech Republic.

Remarks: Up to date there are four Caryospora spp. described from the snakes of the genus Psammophis (Table 1) in sub-Saharan Africa. Caryospora hermae Bray, 1960 is the most similar to our isolate in size and other morphological characteristics. Our isolate seemed to have slightly yellowish wall, possibly caused by uptake of potassium dichromate from the storage medium. The oocyst wall of C. hermae is described as colourless (Bray 1960). Caryospora weyerae Bray, 1960 , reported by the original author to resemble $C$. hermae in every way except the size, thus is smaller than our isolate too. Caryospora psammophi Bray, 1960 has larger oocysts and sporocysts and has pitted oocyst wall. In the original description (Bray 1960), there are poor details about the Stieda and substieda bodies, except a solo description of the Stieda body of $C$. psammophi. However, minute Stieda and substieda bodies for all three species are indicated on schematic diagrams in the original description (Bray 1960, p. 318, figs. 28-30). Shape and size of the oocysts of the present isolate are also within the ranges of Caryospora legeri Hoare, 1933. Our isolate differs from $C$. legeri in the absence of micropyle and in a different shape of the Stieda and substieda bodies. However, the original description of micropyle is probably erroneous (see Discussion).

\section{Caryospora sp. II}

Figs. 6-7, 11

Description: Oocysts oval, $33.6(32-36) \times 27.6(26-$ $30), \mathrm{SI}=1.2(1.1-1.4)(\mathrm{n}=30)$. Oocyst wall slightly pitted, approximately 2 thick, bilayered. Outer layer yellow and thicker than the inner one. Micropyle, oocyst residuum and polar granule absent. Sporocysts oval, $19.8(18-21) \times 13.9(13-14)$, SI $=1.4(1.3-1.5)(n$ $=30$ ). Sporozoites with distinct oval nucleus, refractile bodies hardly visible. Surface of banana-shaped sporozoites transversally striated. Sporocyst residuum usually consists of few small globules of less than 1.5 in diameter, symmetrically scattered among sporozoites in central part of sporocyst. Eight sporozoites, each 1.5-2 in diameter, fill sporocyst. There is clear space in between sporozoites and substieda body. Stieda body ellipsoidal, $3 \times 1$, substieda body ellipsoidal, 3.5-4 $\times$ 1.5.

H o s t : Psammophis orientalis Broadley, 1977 (Serpentes, Colubridae).

L o c a 1 i t y : Watamu near Malindi, coastal area of Kenya, Africa.

Site of infection: Unknown, recovered from faeces. P r e v a l e n c e : Isolated from a single specimen examined.

Site of infection: Unknown, recovered from faeces.

$\mathrm{Vou}$ c h e r m a t e r i a 1 : Oocyst microphotographs deposited under the original collection No. KA24/1999 at Department of Parasitology, University of Veterinary and Pharmaceutical Sciences Brno, Czech Republic.

Remarks: From all known Caryospora spp. of Psammophis from sub-Saharan Africa (Table 1), our form closely resembles Caryospora psammophi Bray, 1960 in oocyst dimensions, shape and an oocyst wall texture and colour. Limited data on the Stieda and substieda bodies of C. psammophi make a finer comparison impossible. Caryospora legeri Hoare, 1933, C. hermae Bray, 1960 and C. weyerae Bray, 1960 differ in the size and character of the oocyst wall. Caryospora 

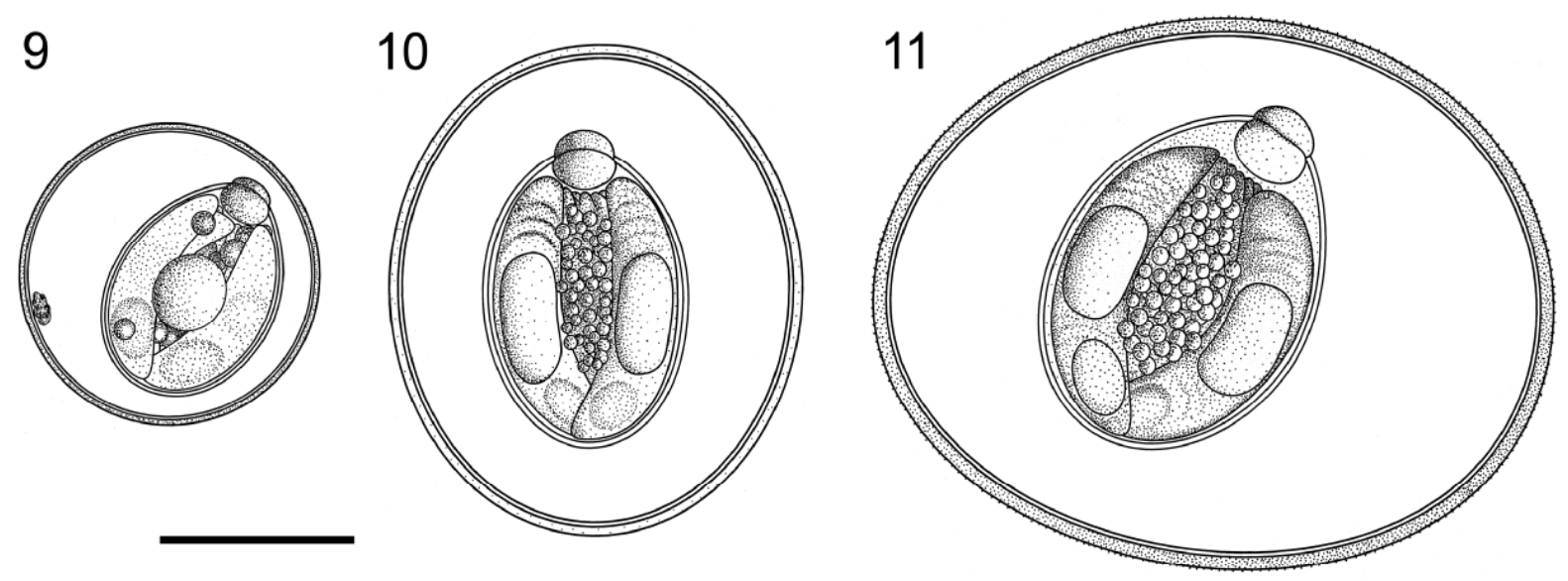

Figs. 9-11. Composite line drawings of sporulated oocysts, all in the same scale. Fig. 9. Caryospora cf. regentensis. Fig. 10. Caryospora sp. I. Fig. 11. Caryospora sp. II. Scale bar $=10 \mu \mathrm{m}$.

maxima Modrý, Koudela, Al-Oran et Amr, 1999 from P. schokari from the Near East has exceptionally large oocysts and thus could not be confused with any of Caryospora forms from sub-Saharan Psammophis (Modrý et al. 1999).

\section{DISCUSSION}

Generally, coccidian oocysts possess a limited amount of morphological features and some of these characters may even vary. Duszynski and Wilber (1997) proposed and set minimal guidance for the description of coccidian species. Proper species differentiation based on the morphology and further biological characteristics has been critically reviewed mostly in species parasitizing mammalian hosts (for review see Duszynski and Upton 2001). Studies on eimerian coccidia from reptilian hosts are still in their infancy, but one can imagine that we face similar problem and a revision of monoxenous coccidia in reptiles would be greatly appreciated.

The phylogeny of Eimeria s.l. coccidia from coldblooded vertebrates still awaits elucidation. Moreover, the status of the genera Choleoeimeria and Acroeimeria proposed by Paperna and Landsberg $(1989 \mathrm{a}, \mathrm{b})$ is not clear. It is evident that biliary eimerians from reptiles form a distinct and easily distinguishable assemblage of species. These coccidia possess oocysts of cylindrical shape and, instead of Stieda and substieda bodies, have sporocyst walls consisting of two plates joined by a longitudinal suture. The morphological variation within this group is limited and observable morphological features are of limited value for distinguishing species. Therefore, the host systematics is considered to be important in defining new species and host specificity on the genus or family level is usually expected. This approach tentatively implies strict host-parasite coevolution, unfortunately without any experimental or other support. On the other hand, the conspecificity of taxa from hosts from distant zoogeographical regions is unlikely. Eimeria arabukosokokensis is the first species described from the cat snakes of the genus Telescopus and no species with similar oocyst morphology has been described from snakes from the African continent. Based on these biological consequences we describe the species found in Telescopus semiannulatus as new.

The genus Caryospora represents the most diversified coccidian genus occurring in snakes. So far, about 43 species were named from these hosts (Modrý 1999), which complicates the taxonomy and describing new species. Descriptions of all species are based predominantly on oocyst morphology, which is in some instances surprisingly variable, e.g., in Caryospora colubris (Matuschka 1984, Paperna and Finkelman 1991). In many cases, however, the species described have not been found since the original description and host specificity of nearly all species is unknown. In some cases, co-occurrence of two or three species in a single host specimen has been reported (Bray 1960, Modrý and Koudela 1998). In contrast, Caryospora duszynskii, the only experimentally studied species from colubrids, has a relatively wide host spectrum, thus low host specificity, including at least four species of NorthAmerican snakes in three genera: Elaphe, Masticophis and Lampropeltis (Upton et al. 1984, McAllister et al. 1995, Modrý unpubl. observ.). Taken together, the taxonomy of Caryospora in colubrid hosts, as practised 
Table 1. Comparison of known Caryospora species in snakes of the genus Psammophis in sub-Saharan Africa (all these Caryospora species are regarded as species inquirendae) ${ }^{1}$

\begin{tabular}{|c|c|c|c|c|c|c|c|}
\hline & Caryospora "legeri" & Caryospora legeri & $\begin{array}{l}\text { Caryospora } \\
\text { psammophi }\end{array}$ & Caryospora hermae & $\begin{array}{l}\text { Caryospora } \\
\text { weyerae } 2\end{array}$ & Caryospora sp. I & Caryospora sp. II \\
\hline Oocyst & $\begin{array}{l}33.0 \pm 1.7(29.8-36.0) \times \\
29.3 \pm 1.3(27-32.4) \\
\mathrm{SI}=1.31 \\
\text { subspherical }\end{array}$ & $\begin{array}{l}20.8-30.4 \times \\
19.2-25.6 \\
\text { subspherical or } \\
\text { slightly ovoid } \\
\end{array}$ & $\begin{array}{l}29.1(25-34) \times \\
26.8(23-31) \\
\mathrm{SI}=1.09 \\
\text { subspherical }\end{array}$ & $\begin{array}{l}22.3(21-24) \times \\
20.6(20-22) \\
\mathrm{SI}=1.08 \\
\text { subspherical }\end{array}$ & $\begin{array}{l}16.1(14-18) \times \\
14.9(13-17) \\
\mathrm{SI}=1.08 \\
\text { subspherical }\end{array}$ & $\begin{array}{l}23.8(22-25.5) \times \\
20.5(19-22) \\
\text { SI }=1.2(1.1-1.3) \\
\text { oval }\end{array}$ & $\begin{array}{l}33.6(32-36) \times \\
27.6(26-30) \\
\mathrm{SI}=1.2(1.1-1.4) \\
\text { oval }\end{array}$ \\
\hline Sporocyst & $\begin{array}{l}22.0 \pm 0.8(20.8-23.4) \times \\
13.1 \pm 0.8(12.6-14.2) \\
\text { ovoid }\end{array}$ & $\begin{array}{l}16.4-19.2 \times \\
11.2-13.6 \\
\text { ovoid }\end{array}$ & $\begin{array}{l}20.8(19-23) \times \\
15.5(13-16) \\
\text { SI }=1.44 \\
\text { ovoid, relatively } \\
\text { thick, colourless } \\
\text { double wall }\end{array}$ & $\begin{array}{l}16.5(16-17) \times \\
12.6(12-13) \\
\mathrm{SI}=1.31 \\
\text { ovoid }\end{array}$ & $\begin{array}{l}13.3(13-14) \times \\
10.0(9-11) \\
\text { SI }=1.34 \\
\text { ovoid }\end{array}$ & $\begin{array}{l}15.5(15-16) \times \\
11.0(10-12) \\
\text { SI }=1.4(1.2-1.6) \\
\text { oval }\end{array}$ & $\begin{array}{l}19.8(18-21) \times \\
13.9(13-14) \\
\mathrm{SI}=1.4(1.3-1.5) \\
\text { oval }\end{array}$ \\
\hline Oocyst wall & n.a. & $\begin{array}{l}\text { thick, greyish } \\
\text { coloured wall, } \\
\text { consisting of two } \\
\text { layers }\end{array}$ & $\begin{array}{l}\text { bilayered, thin } \\
\text { layers, outer finely } \\
\text { and irregularly } \\
\text { pitted, yellow in } \\
\text { colour }\end{array}$ & $\begin{array}{l}\text { bilayered, smooth, } \\
\text { colourless }\end{array}$ & $\begin{array}{l}\text { bilayered, smooth, } \\
\text { colourless }\end{array}$ & $\begin{array}{l}\text { bilayered, } \sim 1.5, \text { outer } \\
\text { thicker, smooth and } \\
\text { yellowish }\end{array}$ & $\begin{array}{l}\text { bilayered } \sim 2 \text {, slightly } \\
\text { pitted, outer thicker } \\
\text { and yellow }\end{array}$ \\
\hline Micropyle & no & minute funnel shaped $^{3}$ & no & no & no & no & no \\
\hline $\begin{array}{l}\text { Stieda body } \\
\text { (SB) and } \\
\text { substieda } \\
\text { body (SSB) }\end{array}$ & $\begin{array}{l}\text { SB: present } \\
\text { SSB: present } \\
\text { (difficult to see), } \\
\text { wider than Stieda } \\
\text { body but thinner } \\
\end{array}$ & $\begin{array}{l}\text { SB: globe-like "knob" } \\
\text { SSB: hemispherical } \\
\text { plug }\end{array}$ & $\begin{array}{l}\text { SB: plug, like a } \\
\text { rounded rubber } \\
\text { stopper jammed into } \\
\text { the sporocyst's neck } \\
\text { SSB: n.a. }\end{array}$ & $\begin{array}{l}\text { SB: n.a. } \\
\text { SSB: n.a. }\end{array}$ & $\begin{array}{l}\text { SB: n.a. } \\
\text { SSB: n.a. }\end{array}$ & $\begin{array}{l}\text { SB: ellipsoidal } 2.5-3 \times 1 \\
\text { SSB: oval } 3-3.5 \times 1.5\end{array}$ & $\begin{array}{l}\text { SB: ellipsoidal } 3 \times 1 \\
\text { SSB: oval } 3.5-4 \times 1.5\end{array}$ \\
\hline $\begin{array}{l}\text { Sporocyst } \\
\text { residuum }\end{array}$ & $\begin{array}{l}\text { present, granular } \\
\text { large mass }\end{array}$ & $\begin{array}{l}\text { present (centrally, } \\
\text { bulky granular) }\end{array}$ & $\begin{array}{l}\text { present (centrally, } \\
\text { diffuse) }\end{array}$ & $\begin{array}{l}\text { present (widely } \\
\text { scattered) }\end{array}$ & present (some) & $\begin{array}{l}\text { small globules }<0.5 \text {, fill } \\
\text { the sporocyst }\end{array}$ & $\begin{array}{l}\text { few small globules } \\
<0.5 \text {, symmetrically } \\
\text { in central part }\end{array}$ \\
\hline Sporulation & n.a. & 2 days & n.a. & n.a. & n.a. & n.a. & n.a. \\
\hline $\begin{array}{l}\text { Site of } \\
\text { infection }\end{array}$ & n.a. & small intestine & small intestine & small intestine & small intestine & n.a. & n.a. \\
\hline $\begin{array}{l}\text { Host and } \\
\text { prevalence }\end{array}$ & $\begin{array}{l}\text { P. sibilans } \\
\quad(1 / 1)\end{array}$ & $\begin{array}{l}\text { P. sibilans } \\
\quad(2 / 3)\end{array}$ & $\begin{array}{l}\text { P. s. phillipsi } \\
(1 / 4)\end{array}$ & $\begin{array}{l}\text { P. s. phillipsi } \\
(1 / 4)\end{array}$ & $\begin{array}{l}\text { P. s. phillipsi } \\
(1 / 4)\end{array}$ & $\begin{array}{l}\text { P. orientalis } \\
\qquad(1 / 1)\end{array}$ & $\begin{array}{l}\text { P. orientalis } \\
(1 / 1)\end{array}$ \\
\hline Type locality & Nigeria & Entebbe, Uganda & Liberia & Liberia & Liberia & Kenya & Kenya \\
\hline Reference & $\begin{array}{c}\text { Daszak and Ball } \\
\text { 2001a }\end{array}$ & Hoare 1933 & Bray 1960 & Bray 1960 & Bray 1960 & this study & this study \\
\hline
\end{tabular}

${ }^{1}$ data and wording as given in the original descriptions, measurements in micrometres, all isolates with no oocyst residuum and no polar granule; n.a. - not available; SI - shape index; ${ }^{2}$ resembles C. hermae in every way except the size (Bray 1960$){ }^{3}$ probably misidentification. 
by authors up to now, reaches in some cases nearly the "dead end" and the species parasitizing the genus Psammophis represent such an example.

So far, there are eight species of Caryospora described from snakes from sub-Saharan Africa (Hoare 1933, Bray 1960, Matuschka 1982, Upton et al. 1992, Daszak and Ball 2001a). In addition to four species from hosts of the genus Psammophis (Table 1) we are aware of only four additional species of the genus Caryospora described from sub-Saharan snakes, namely $C$. heterodermus Upton, Freed et Freed, 1992 from Philothamnus heterodermus (Colubridae), $C$. maculatus Upton, Freed et Freed, 1992 from Causus maculatus (Viperidae), C. najae Matuschka, 1982 from Naja nigricollis (Elapidae) and C. regentensis Daszak et Ball, 2001 from Dendroaspis angusticeps (Elapidae). All these species can be distinguished based on the oocyst morphology and their conspecificity with Caryospora isolates reported in our study is unlikely.

The taxonomy and diagnosis of Caryospora spp. parasitizing sub-Saharan colubrid snakes of the genus Psammophis is somewhat more complex. Four caryosporan species have been described from these hosts to date. Hoare (1933) described Caryospora legeri from $P$. s. sibilans from Entebe, Uganda. The description is rather precise, including notes on endogenous stages. However, he noted in some oocysts a minute, funnelshaped micropyle. Since the presence of a micropyle has not been described in any other Caryospora species, it is probable that Hoare's observation of this structure was erroneous. Bray (1960) described three additional spe-cies of Caryospora from P. (sibilans) phillipsi from Liberia (C. psammophi, C. hermae and C. weyerae). All three species occurred in a single host specimen examin-ed and they differ mostly in the oocyst/sporocyst dimen-sions and oocyst wall texture (see Table 1). Inter-estingly, three size-wise differing categories of oocysts were described in Coluber viridiflavus from Italy, but considered to represent a single species Caryospora colubris (Matuschka 1984). The variation in merozoites and microgametes has been suggested to be a valuable character for species differentiation where oocyst morphology is ambiguous (Paperna and Finkelman 1991).

Recently, Daszak and Ball (2001a) reported on an isolate of Caryospora in Psammophis sibilans from Kenya and re-analysed descriptions of Caryospora legeri Hoare, 1933, C. psammophi Bray, 1960, C. hermae Bray, 1960 and C. weyerae Bray, 1960. Based on overlapping oocyst morphology, they synonymised
C. psammophi and C. hermae with C. legeri, which brought the total number of Caryospora species parasitizing Psammophis in entire sub-Saharan Africa to two: $C$. legeri and $C$. weyerae. In this study, we report on two distinct forms of Caryospora from a single $P$. orientalis from coastal Kenya. Both forms do not overlap morphometrically and differ also in fine appearance of oocyst wall, Stieda and substieda bodies and sporocyst residuum. On the other hand, morphological characteristics of the oocysts and the sporocysts overlap with those of several above mentioned species described from African Psammophis. Since we were not able to associate the two studied forms with any of described taxa we did not use any of the existing names. Based on the occurrence of two morphologically distinguishable forms of Caryospora that we found in faeces of $P$. orientalis from Watamu, we consider the synonymical changes proposed by Daszak and Ball (2001a) be precocious. The generalisation of $C$. legeri description may lead to confusions and may cause, in our opinion, an underestimation of the diversity of Caryospora in the region. Moreover, the genus Psammophis Boie, 1827 is a taxonomically complicated assemblage of species awaiting a full revision and the situation in coastal East Africa is not an exception (Spawls et al. 2002). Described taxa of the Psammophis sibilans-complex are closely related and some are considered to be conspecific by various authors (e.g., Broadley 1966, 1977, Pitman 1974, Broadley and Howell 1989, Trape and Roux-Estève 1995). All Caryospora species named from these hosts (Hoare 1933, Bray 1960, Daszak and Ball 2001a) were described without detailed data on type-host specimens and without host symbiotypes deposited. Because of all above mentioned problems we propose to treat all species of Caryospora from sub-Saharan Psammophis as species inquirendae until a detailed study based on a wider material from well-defined and properly determined hosts is available. However, such study is virtually impossible without full revision of the genus Psammophis in Africa.

Acknowledgements. The visit of J.R.Š and D.M. to Kenya was kindly supported by Masokombinát Písek a.s. and by the Nadání Josefa a Marie Hlávkových endowment. Asad Anwar gave useful practical information and kindly provided accommodation in Nairobi. We thank Dr. L. Hájek for generous support and Sanda Ashe for nice discussion and help with collection of samples in Bio-Ken Watamu. This study was supported by the grant No. 524/00/P015 of the Grant Agency of the Czech Republic. 


\section{REFERENCES}

ASMUNDSSON I.M., UPTON S.J., FREED P.S. 2001: Five new species of coccidia (Apicomplexa: Eimeriidae) from colubrid snakes of Ecuador. J. Parasitol. 87: 1077-1081.

BRAY R.S. 1960: On the parasitic protozoa of Liberia. III. Three new species of Caryospora Léger, 1904 from the hissing sand snake Psammophis sibilans phillipsi and a note on a Caryospora in Coluber ravergieri nummifer from Israel. J. Protozool. 7: 314-320.

BROADLEY D.G. 1966: A review of the African striped bellied sand snakes of the genus Psammophis. Arnoldia 2: $1-9$.

BROADLEY D.G. 1977: A review of the genus Psammophis in Southern Africa (Serpentes: Colubridae). Arnoldia 8: 129.

BROADLEY D.G., HOWELL K.M. 1989: A check list of the reptiles of Tanzania, with synoptic keys. Syntarsus 1: 170.

DASZAK P., BALL S.J. 2001a: A description of two new species of coccidia (Apicomplexa: Eimeriidae) from African reptiles with nomenclatural corrections for two Caryospora and one Eimeria species from snakes. Folia Parasitol. 48: 1-6.

DASZAK P., BALL S.J. 2001b: Corrigendum. A description of two new species of coccidia (Apicomplexa: Eimeriidae) from African reptiles with nomenclatural corrections for two Caryospora and one Eimeria species from snakes. Folia Parasitol. 48: 162.

DUSZYNSKI D.W., UPTON S.J. 2001: Cyclospora, Eimeria, Isospora, and Cryptosporidium. In: W.M. Samuel, M.J. Pybus and A.A. Kocan (Eds.), Parasitic Diseases of Wild Mammals. Mason Publishing / The Veterinary Press, London, pp. 416-459.

DUSZYNSKI D.W., WILBER P.G. 1997: A guideline for the preparation of species description in the Eimeriidae. J. Parasitol. 83: 333-336.

HOARE C.A. 1933: Studies on some new ophidian and avian coccidia from Uganda, with a revision of the classification of the Eimeriidae. Parasitology 25: 359-388.

MATUSCHKA F.-R. 1982.: Caryospora najae sp. $\mathrm{n}$. (Apicomplexa: Sporozoea, Eimeriidae) from the spitting cobra, Naja nigricollis pallida (Serpentes: Elapidae). J. Parasitol. 68: 1149-1153.

MATUSCHKA F.-R. 1984: Description of Caryospora colubris sp.n. (Apicomplexa: Eimeriidae) from the western whip snake, Coluber viridiflavus (Serpentes: Colubridae). Can. J. Zool. 62: 1525-1527.

McALLISTER C.T., UPTON S.J., TRAUTH S.E., DIXON J.R. 1995: Coccidian parasites (Apicomplexa) from snakes in the southcentral and southwestern United States: new host and geographic records. J. Parasitol. 81: 63-68.

MODRÝ D. 1999: The Biology and Pathogenicity of Caryosporan Coccidia. PhD Thesis, University of Veterinary and Pharmaceutical Sciences, Brno, 52 pp.
MODRÝ D., DASZAK P., VOLF J., VESELÝ M., BALL S.J., KOUDELA B. 2001: Five new species of coccidia (Apicomplexa: Eimeriidae) from Madagascan chameleons (Reptilia: Chamaeleonidae). Syst. Parasitol. 48: 117-123.

MODRÝ D., KOUDELA B. 1998: Coccidia of the genus Caryospora (Apicomplexa: Eimeriidae) from the long nosed vine snake, Ahaetulla nasuta (Serpentes: Colubridae: Boiginae) from southern India, with a description of $C$. veselyi sp. n. Folia Parasitol. 45: 167169.

MODRÝ D., KOUDELA B., AL-ORAN R.M., AMR Z.S. 1999: Caryospora maxima sp. n. (Apicomplexa: Eimeriidae), new coccidium from Forskal's sand snake, Psammophis schokari (Serpentes: Colubridae) from lava desert of Jordan. Folia Parasitol. 46: 96-98.

PAPERNA I., FINKELMAN S. 1991: Development of Caryospora colubris (Apicomplexa: Eimeriidae) in the Syrian Black Snake Coluber jugularis L. Ann. Parasitol. Hum. Comp. 66: 91-95.

PAPERNA I., LAINSON R. 2000: Ultrastructural study of meronts and gamonts of Choleoeimeria rochalimai (Apicomplexa: Eimeriidae) developing in the gall bladder of the gecko Hemidactylus mabouia from Brazil. Folia Parasitol. 47: 91-96.

PAPERNA I., LANDSBERG J.H. 1989a: Fine-structure of endogenous stages of Eimeria turcicus developing in gallbladder epithelium of the gecko Hemidactylus turcicus. S. Afr. J. Zool. 24: 251-259.

PAPERNA I., LANDSBERG J.H. 1989b: Description and taxonomic discussion of eimerian coccidia from African and Levantine geckoes. S. Afr. J. Zool. 24: 345-355.

PITMAN C.R.S. 1974: A Guide to the Snakes of Uganda. Whelton and Wesley, Coticode, $290 \mathrm{pp}$.

SPAWLS S., HOWELL K., DREWS R., ASHE J. 2002: A Field Guide to the Reptiles of East Africa. Academic Press, San Diego, 543 pp.

TRAPE J.F., ROUX-ESTËVE R. 1995: Les serpents du Congo: liste commentée et clé de détermination. J. Afr. Zool. 109: 31-50.

UPTON S.J., CURRENT W.L., BARNARD S.M. 1984: A new species of Caryospora (Apicomplexa: Eimeriorina) from Elaphe spp. (Serpentes: Colubridae) of the southeastern and central United States. Trans. Am. Microsc. Soc. 103: 240-244.

UPTON S.J., CURRENT W.L., BARNARD S.M. 1986: A review of the genus Caryospora Léger, 1904 (Apicomplexa: Eimeriidae). Syst. Parasitol. 8: 3-21.

UPTON S.J., FREED P.S., FREED M.G. 1992: Two new species of Caryospora (Apicomplexa) from snakes in Cameroon, with redescriptions of two coccidians from Hemidactylus mabouia (Gekkonidae). Syst. Parasitol. 23: 135-140.

Accepted 11 July 2002 